\title{
Implementation of Integrated Quality in the Manado State Politechnic Tourism Department
}

\section{Bernadain D. Polii, Diane Tangian, and Hendry Kumaat}

Tourism Department Manado State Polytechnic. Indonesia

\section{Abstract}

This study aims to identify and analyze the implementation of integrated quality management in the Department of Tourism Politeknik Negeri Manado. Integrated Quality Management (MMT) is a quality control system based on the philosophy that meeting the needs of the customers is the main concern in every business. To meet every employee who is involved in the education, motivation, attitude, willingness and dedication are the most important parts of the work culture.

In this study, the main instrument is the researchers themselves, as a means of collecting

Corresponding Author:

Bernadain D. Polii

gibloki10@gmail.com

Received: 11 January 2019

Accepted: 14 February 2019

Published: 25 March 2019

Publishing services provided by Knowledge E

(c) Bernadain D. Polii et al. This article is distributed under the terms of the Creative Commons Attribution License, which permits unrestricted use and redistribution provided that the original author and source are credited.

Selection and Peer-review under the responsibility of the 3rd ICTVET 2018 Conference Committee.

\section{G OPEN ACCESS} data. Researchers directly observe, ask, track, understand and analyze everything that happens on location. The planning process has involved all the components and stakeholders and this planning has been poured into the quality objectives of the department that are temporarily implemented by the department's leaders. Management integrated quality in the tourism department has been accomplished in accordance with the joint commitment of Manado State Polytechnic level and by running the Standard Operating Procedure (SOP). Integrated quality management on affairs encounters various obstacles. Obstacles that occur among which are labor management that has not been maximal, inadequate facilities and infrastructure as well as human resources that have not contributed optimally. Alternative solutions to the obstacles have been pursued by the head of department.

Keywords: Integrated Quality, Management, Education

\section{Introduction}

Gryna, Chua and DeFeo say Quality is "customer satisfaction and loyalty,[1] Quality is an unusually slippery concept, easy to visualize and yet exasperatingly difficult to define.[2] "Quality is the basic customer decision factor for an explosively growing number of products and services today.[3]

Quality according to Jerome Arcaro is: "A structured process to improve the resulting output. Quality is not a magical object or something complicated.[4] Quality is:" Everything that can meet the needs of customers.[5] And according to [6] there are 
nine dimensions in quality, those are: (1) Conformance, (2) Performance, (3) Features, (4) Durability, (5) Reliability, (6) Service, (7), Response, (8) Reputation, (9) Aesthetics.

According to Sallis [7] TQM is: A philosophy of continuous improvement, which can provide a set of practical tools to every educational institution to meet the needs, wishes, and expectations of its customers, now and for the future. Based on the above understanding, Total Quality Management (Integrated Quality Management) is a solemn commitment undertaken by the organization to improve long-term quality and provide satisfactory service for customers.

According to Sallis, as has been stated before that the concept of quality has three meanings, namely: quality as an absolute or absolute concept; quality in relative concepts; and quality according to the consumer.

\section{Methods}

\subsection{Place of research}

This research was conducted in Manado State Polytechnic Tourism Department, Buha Village, Mapanget Sub District, Manado City.

\subsection{Time of research}

This research was conducted within a period of more than five months counted since the preparation of research proposal.

\subsection{Data and data sources}

Data used in this research is descriptive data, in the form of document, result of field observation, and speech of respondent. The data is collected by the researcher himself by entering the field and recorded on the field notebook.

\subsection{Data collection}

In this study, the main instrument is the researchers themselves, as a means of collecting data. The researchers directly observe, ask, track, understand and analyze everything that happens at the research site. Researchers have also used an instrument support such as field notes, tape recorder and camera images. 
In this study were used research techniques advocated by Moleong [8] as follows:

1). Observation 2). Interview 3). Documentation Study 4). Making Field Notes

\subsection{Data analysis}

Data analysis can be done throughout the research process namely (1) data reduction, (2) arranging in units, (3) categorizing, (4) conducting validity checks of data, (5) interpretation and decision making.

\subsubsection{Data validity checking}

The data obtained through data collection checking for validity as recommended by Moleong [8] includes credibility test, transferability test, dependability test and confirmability test. For details of the four validity checks and test of data above will be explained as follows:

\subsubsection{Transferability}

In this study, researchers try to build the value of transfer by way of reporting the results of research as accurate as possible.

\subsubsection{Dependability}

Dependability is a requirement for validity. The test is carried out in a manner called audit trail to ensure the veracity of naturalistic research.

\subsubsection{Confirmability}

This research is a scientific effort conducted by researchers in a disciplined manner, associated with qualitative research principles and open to inspection and verification by the reader.

\section{Disscucussion}




\subsection{Integrated quality management planning at tourism depart- ment of Manado state polytechnic}

From exposure to interview about the planning process, it was the department head along with the department and administrative staff that have made this plan with reference to the needs of the industry (industrial needs) and also the findings of the circumstances at the polytechnics and the tourism department. This is in accordance with the system of education in polytechnics conducting vocational education, which serves to develop learners to a higher level of education in order to have a specific job applying skills appropriate with labor market requirements in order to achieve the goal of national education. The formulation of an integrated quality planning is made through a technical meeting held by the Department of Tourism.

With the above findings, it can be concluded that the tourism department had planned quality objectives as outlined in the majors. Preparation of this plan has been reviewed in advance by using SWOT analysis to determine the strengths, weaknesses, opportunities, threats that the department of tourism has.

\subsection{Implementation of integrated quality management at tourism department of Manado state polytechnic}

A study revealed that the tourism department has implemented an integrated quality management since 2007. From these results can be described as follows: lack of commitment by the leadership to hold meetings with the department and staff with the vision and mission as well as disseminating the integrated quality management which will be achieved by the department and the head of department appointed an experienced senior lecturer to be the coordinator of the Quality Assurance (QA) to assist the department in order to implement total quality management, in addition to forming the QA team, also forming coordinator expertise $(C B C)$ whose jobs are to assess and to set up goals profession / occupations, to determine the competence of graduates and to convert competencies of graduates to the course, networks between subjects, the structure of courses, distribution of courses per semester, schedule, syllabus / GBPP, SAP, modules, textbooks, guidelines for laboratory practice, guidelines for field work, and to write the final report. QA Coordinator assisted by two lecturers and employees prepare devices to be used during the activity in the majors. These devices made reference of Standard Operating Procedures (SOP), which is set at the beginning of the planning meetings in Manado State Polytechnic level, the manufacture of this SOP has also formed a small team drawn from the lecturers that exist in every respective 
department, each department was represented by three people, those who organized the SOP also had to see the results of the needs of industry and the results of the findings obtained from the majors. Activities to be regulated in SOP form: attendance of teachers, attendance of students, learning of theory, instructional practices, grading course practice, grading courses theory, giving a reprimand and sanctions to lecturers in the learning process, the implementation of the midterms, and final exams, preparing about midterms and final exams, the examination results of the midterm and final exams, material procurement practices, curriculum development, a final evaluation process of learning, graduation at end of the semester, the determination of the supervisor, minor thesis, industry visit, the use of the tool in labs, minor thesis seminar and exam, publishing, distribution and archiving of KHS of students, student absenteeism control, the proposed increase in functional positions of lecturers, control of working hours of lecturers, professors election example, research activities.

From the observation that after implementers integrated quality management in the Department of Tourism and ran it, it was shown that, in terms of the results of the midterm until the results of semester exams there is an increase in quality, and also in terms of the presence of students, faculty and employees of improvement, system of administration activities got better but needs more increase.

\subsection{Obstacles in the implementation of an integrated quality man- agement at tourism department of Manado state polytechnic}

Based on the findings of the implementation of total quality management, it has been running but still some obstacles are encountered. Various kinds of obstacles that require significant reduction efforts continued in all related elements. Such constraints occurred because the head of department was less assertive in making decisions, giving additional tasks that bring in additional revenue as a tribute often delegated to certain lecturers and administrative staff, as well as in the provision of opportunity to follow education and training, the committee's activities, the integrated quality has not been implemented by all parties in the sense that there has been no total involvement of of strong working team, limited funds available to hold trainings for the lecturers and administrative staff in order to improve competence, the use of which has not referred to laboratory SOP that has been set, the facilities and infrastructure that have not been complete that students are not optimal in carrying out the study of theory or practice, there are professors who have carried out these responsibilities in class, this could cause lack of moral strength because it is not supported by adequate competence. 
Resolving while eliminating barriers is not easy. It must be through a common struggle.

\subsection{The solution to the obstacles in the implementation of total quality management in the department of Manado state poly- technic tourism}

The research results show that the department head in decision-making is still with his heart instead of using the supporting data. So the solution is that more decisions made by the head of department and the work division is in accordance with the competence regardless of the proximity, and equal opportunities as well the tasks that bring in additional income and provide equal opportunity also to every person in training, for those who do a good job are given the reward and for those who do not perform their jobs well are given punishment.

As we know, higher education quality assurance was born because of the problems in the field faced by the education quality in Indonesia. Department of Tourism seeks to improve the quality of education in this direction by seeking to overcome the obstacles that occur during this time. So the right solutions are in the forms of: involving all the components in the majors in making decisions such as lecturers, staff, students, involving faculty and administrative staff in the training such as entrepreneurship, teaching methodology, Quality Assurance, internship lecturers to industries both within and outside the area.

\section{Conclusion}

Based on the exposure, the findings and the discussion focused on the Integrated Quality Management Implementation at Manado State Polytechnic,Tourism Department drew the following conclusions:

1. The planning process has gone through the SWOT analysis beforehand to know the opportunities, challenges, the reality, and hope that will be done by the department in the future.

2. Implementation of integrated quality management in the tourism department has been accomplished in accordance with the joint commitment of Manado State Polytechnic level and by running the Standard Operating Procedure (SOP). Although it has not been accomplished in accordance with what was expected, 
but the leaders of the Department have been trying to improve the integrated quality while using the tools and techniques of continuous quality improvement.

3. Implementation of integrated quality management at the Department encounters many obstacles. Barriers may include: assertiveness of department leadership, laboratory management has not been effective, infrastructure is inadequate and human resources have not contributed excellently.

4. Alternative solutions to the barriers have already been pursued by the head of department in a way to be more assertive in decision-making, allowing interchangeability in following education and training or an internship as well as the committee and the like, fix the administration that has not been managed well, the addition of laboratory equipment and further improvement of the function of head of the laboratory, provide an opportunity for teachers to pursue further studies, improve education through an increase in the course of DIII to Applied S1, provide internship opportunities for lecturers, staff and students from the region.

\section{References}

[1] Gryna, Frank M, Richard C.,et.al.(2007) Quality Planning And Analysis For Enterprice Quality. USA: McRaw-Hill.

[2] Adrian Wilkinson, Tom Redman,(1998). Managing With Total Quality Management (Theory and Practice) London:Macmillan Press LTD.

[3] ArmandV, Feigbaum.(1998) Total Quality Control.New York:McGraw-Hills.

[4] Jerome Arcaro. (2005) Based Education Quality. Yogyakarta: Student Library.

[5] Gupta, Srinivasa.,et.al. (2009) Total Quality Management. New Delhi: McGraw-Hills Office.

[6] Vincent Gasperz.(2006) Sistem Manajemen Kinerja Terintegrasi Balanced Scorecard dengan Six Sigma untuk Organisasi Bisnis dan Pemerintah:PT Gramedia Pustaka Utama: Jakarta.

[7] Edward Sallis. (2012) Total Quality Management in Education. USA: Quicksilver Drive.

[8] Sugiyono.(2005). Statistical Methods for Research. Bandung: Alfabeta.

[9] __. (2012) Research Methods Combination. Bandung: Alfabeta. 